1987

\title{
Economic Rights of the Institutionalized Mentally Disabled
}

Michael L. Perlin

New York Law School, michael.perlin@nyls.edu

Follow this and additional works at: https://digitalcommons.nyls.edu/fac_articles_chapters

Part of the Law and Economics Commons, and the Law and Psychology Commons

\section{Recommended Citation}

Perlin, Michael L., "Economic Rights of the Institutionalized Mentally Disabled" (1987). Articles \& Chapters. 1155.

https://digitalcommons.nyls.edu/fac_articles_chapters/1155 


\title{
Economic Rights of the Institutionalized Mentally Disabled
}

\author{
Michael L. Perlin*
}

\section{Introduction}

The "explosion" of litigation and legislation in all aspects of mental disability law over the past 15 years has been well documented in the caselaw, ${ }^{2}$ in state and federal statutes, ${ }^{3}$ and in the law review literature. ${ }^{4}$ At least nine separate reasons - some of which appear internally paradoxical - seem to have made some significant contribution to this explosion:

1. The activist posture of the Warren Court in the 1960's, leading a wide array of minority groups to come to the federal courts in an attempt to seek vindication of their civil rights.

2. The expansion of this "civil rights revolution" to include mentally disabled persons at a time when revelations of substandard and often-dangerous living conditions in state hospitals and state schools for the mentally retarded first truly sensitized the public to the plight of the institutionalized mentally handicapped.

3. The Supreme Court's continuing fascination with all aspects of the law affecting the mentally disabled.

\footnotetext{
*Associate Professor of Law, New York Law School, 57 Worth St., New York, NY 10013, U.S.A.

The author wishes to thank Mark Dennison for his helpful research assistance.

'See La Fond, An Examination of the Purposes of Involuntary Civil Commitment, 30 BUFF. L. REV. 499 (1981).

${ }^{2}$ See, e.g., O'Connor v. Donaldson, 422 U.S. 563 (1975) (right to liberty); Lessard v. Schmidt, 349 F. Supp. 1078 (E.D. Wis. 1972) (procedural due process in commitment decision-making) (subsequent citations omitted); Wyatt v. Aderholl, 503 F. 2d 1305 (5 Cir. 1974) (right to treatment); Rennie v. Klein, 720 F. 2d 266 (3 Cir. 1983) (right to refuse treatment); Mills v. Rogers, 457 U.S. 291 (right to refuse treatment); Youngberg $v$. Romeo, 457 U.S. 307 (1982) (right to training).

${ }^{3}$ See, e.g., 42 U.S.C. $\$ \$ 6001$ et seq. (1986 Supp.) (Developmentally Disabled Bill of Rights Act); 29 U.S.C. $\$ 794$ (1985) (Section 504 of the Rehabilitation Act of 1973); 42 U.S.C. $\$ \$ 10801$ et seq. (1986 Supp.) (Pamph. III); N.J.S.A. 30:4-24.1 to 24.2 (1981) (state patients' bill of rights).

${ }^{4}$ See e.g., LaFond, supra note 1 (involuntary civil commitment); Cook, The Substantive Due Process Rights of Mentally Disabled Clients, 7 MENT. DIS. L. RPTR. 346 (1983) (right to treatment); Brooks, The Constitutional Right to Refuse Antipsychotic Medication, 8 BULL. AM. ACAD. PSYCH. \& L, 179 (1980) (right to refuse treatment); Ferleger, Anti-Institutionalization and the Supreme Court, 14 RUTGERS L.J. 595 (1983) (right to deinstitutionalization); see generally Brant, Pennhurst, Romeo, \& Rogers, The Burger Court and Mental Health Law 4 J. LEG. MED. 323 (1985).

See also, e.g., Perlin, State Constitutions and Statutes as Sources of Rights for the Mentally Disabled: The Last Frontier? 20 LOY. L.A. L. REV. 1249 (1987) (in press) [hereinafter cited as Last Frontier]; Perlin, The Supreme Court, the Mentally Disabled Criminal Defendant, and Symbolic Values: Random Decisions, Hidden Rationales, or 'Doctrinal Abyss'? 29 Ariz. L. Rev. 1 (1987).
} 
4. The proliferation of state and federal statutes focusing on treatment of the institutionalized mentally disabled and discrimination against the handicapped in community settings.

5. Changes in clinical treatment approaches and in social policy, leading simultaneously to the recognition that mental handicap cannot be seen as a monolithic all-or-nothing condition, and to the deinstitutionalization of thousands of formerly institutionalized individuals.

6. The development of an organized, coherent mental disability bar, resulting in proliferating caselaw, and an inevitable spillover to the rest of the bar.

7. Developments in tort law, expanding the notion of a therapist's "duty to protect" third parties from certain mentally disabled individuals' potentially dangerous actions, coming ironically, at a time when new research techniques have called seriously into question the ability of psychiatrists to accurately predict dangerousness.

8. Public outrage at the Hinckley acquittal, leading to a reexamination of the role of responsibility as an exculpatory defense in criminal law, at a time when new social factors have been considered as possibly expanding the substantive bases of such defenses, and

9. The emergence of state constitutions and statutes as independent sources of such rights for handicapped individuals as the legal pendulum has begun to shift away from expansive federal court readings of individual rights.

As a result of these reasons - which have led both to the expansion of rights of the mentally disableds and, paradoxically, to the contraction of other rights (as a reflection of disenchantment on the part of the public at large and on the part of the federal courts with the notion of vastly expanding the civil rights and civil liberties of the mentally disabled) ${ }^{6}$ - there has been a remarkable proliferation of cases involving almost all aspects of mental disability litigation, especially on behalf of the institutionalized and the formerly-institutionalized.

These cases have involved the articulation of procedural due process rights, substantive due process rights, ${ }^{8}$ the right to treatment or training, ${ }^{9}$ the right to

SThe first six of the listed reasons combined to lead to the development of the caselaw cited supra note 2 and the statutes cited supra note 3. See generally Last Frontier, supra note 4.

'The last three of the enumerated reasons have led to such developments as the passage of the restrictive Insanity Defense Reform Act of 1984 , see 18 U.S.C. $\$ 20$ (1986 Supp.), expanded duties of psychotherapists to protect potential victims from violent patients, see, e.g.. Tarasoff v. Board of Regents of University of California, 17 Cal. 3d 425, 131 Cal. Rptr. 14, 551 P. 2d 334 (Sup. Ct. 1976), and Supreme Court decisions such as Pennhurst State School \& Hospital v. Halderman, 104 S. Ct. 900 (1984) (expanding the scope of the Eleventh Amendment so as to drastically curtail federal suits against state officials in a wide variety of factsettings in cases seeking relief under either pendent state jurisdiction or federal statutes). But see, The Rehabilitation Act Amendments of 1986, P.L. 99-506, \$10032 (a) (1), legislatively limiting the applicability of the Eleventh Amendment in cases involving federal statues prohibiting discrimination against the handicapped.

Pertinent scholarship discussing Pennhurst is collected in Note, The Eleventh Amendment's Lengthy Shadow Over Federal Subject Matter Jurisdiction: Pennhurst State School \& Hospital v. Halderman, 34 DEPAUL L. REV. 515 n.1 (1985).

'See, e.g., Lessard, supra.

'See O'Connor, supra.

'See, e.g., Wyatt, supra; Youngberg supra. 
refuse treatment, ${ }^{10}$ and the right to deinstitutionalization. ${ }^{11}$ What is surprising, however, is the relative paucity of litigation ${ }^{12}$ focusing on the important questions of the scope of economic rights of the institutionalized mentally disabled. ${ }^{13}$

This lack of attention is significant for several reasons. First, there is ample therapeutic evidence that economic self-sufficiency is a critical determinant as to whether an inpatient will ultimately be reintegrated into the community. ${ }^{14}$ Second, as the link between homelessness and deinstitutionalization policies continues to be explored, ${ }^{15}$ it becomes clearer that post-institutional poverty is perhaps the most important factor in determining whether a deinstitutionalized patient will be added to the growing roster of the nation's homeless. ${ }^{16}$ Third, while there have been extensive commentaries - by lawyers and mental health professionals alike - on virtually every facet of such mental disability issues as procedural due process rights, ${ }^{17}$ treatment rights, ${ }^{18}$ and the scope of the right to

${ }^{10}$ See Rennie, supra; Rogers, supra.

${ }^{11}$ See Pennhurst, supra.

${ }^{12}$ Cf. Perlin \& Siggers, The Role of the Lawyer in Mental Health Advocacy, 4 BULL. AM. ACAD. PSYCH. \& L. 204, 209 (1976) (advocacy office's law reform caseload showed "clear pattern in . . . progression from procedural cases to substantive cases to economic cases"). See also Perlin, Ten Years After: Evolving Mental Health Advocacy and Judicial Trends, 15 FORDHAM URBAN L.J. 335, 338 (1986-87) (over past decade, "the first legal awakening of interest in the whole notion of economic rights" has developed).

${ }^{13}$ Contrarily, the Supreme Court has paid some important attention to economic issues of great significance to mental health providers. See, e.g., Blue Shield of Virginia v. McCready, 459 U.S. 465 (1982) (consumer antitrust suit could be maintained where she alleged Blue Shield and state psychiatric association conspired to refuse reimbursement for certain visits to clinical psychologist); see generally Perlin, Recent Developments in Mental Health Law, in 6 Sadoff ed., PSYCHIATRIC CLINICS OF NORTH AMERICA 539, 547-548 (1983).

${ }^{14}$ This issue has been explored most extensively in the context of litigation centering around the question of a patient's right to be paid for institutional labor following the decision in Souder v. Brennan, $367 \mathrm{~F}$. Supp. 808 (D.D.C. 1973) (minimum wage provisions of the federal Fair Labor Standards Act (FLSA) apply to most institutional labor at public mental institutions). See, e.g., Perlin, The Right to Voluntary, Compensated, Therapeutic Work: A New Theory in the Aftermath of Souder, 7 SETON HALL L. REV. 298 (1976) ("Right to Work"); Friedman, The Mentally Handicapped Citizen and Institutional Labor, 87 HARV. L. REV. 567 (1974); see also, e.g., King v. Carey, 405 F. Supp. 41, 44 (W.D.N.Y. 1975).

While the continuing vitality of Souder was sharply questioned following the Supreme Court's decision in National League of Cities v. Usery, 426 U.S. 833 (1976) (aspects of the FLSA extending minimum wage protections to state employees held unconstitutional under the Tenth Amendment), National League has since been overruled in Garcia v. San Antonio Metropolitan Transit Authority, 105 S. Ct. 1005 (1985), raising the question as to whether the Souder methodology might yet be resuscitated. For a recent revisionist view of the appropriateness of applying FLSA provisions to patient labor, see Blaine \& Mason, Application of the Fair Labor Standards Act to Patient Work Programs at Mental Health Institutions: A Proposal for Change, 27 B.C. L. REV. 553 (1986).

15See, e.g., Mills \& Cummins, Deinstitutionalization Revisited, 5 INT'L J. L. \& PSYCHIATRY 271 (1982); Rhoden, The Limits of Liberty: Deinstitutionalization, Homelessness, and Libertarian Theory, 31 EMORY L.J. 375 (1982).

${ }^{16}$ See, e.g., Lipton \& Sabitini, Constructing Social Support Systems for Chronic Patients, in Lamb, ed., THE HOMELESS MENTALLY ILL 153, 156 (1984); Williams et al., Deinstitutionalization and Social Policy: Historical Perspectives and Present Dilemmas, 50 AM. J. ORTHOPSYCH, 54 61-64 (1980). Cf. Saphire, The Civilly-Committed Public Mental Patient and the Right to Aftercare, 4 FLA. ST. U. L. REV. 232, 288 (1976): "Many patients remain in confinement because they are too poor to be released."

${ }^{17}$ See, e.g., LaFond, supra note 1.

${ }^{18}$ See, e.g., Cook, supra note 4; Brant, supra note 4. 
refuse treatment, ${ }^{19}$ the journals have been virtually silent on the entire topic of economic rights of the institutionalized mentally disabled.

This Article will consider some of the underdiscussed economic issues of significance to the institutionalized mentally disabled and their families: (1) the right of the mentally disabled to control their own assets while institutionalized $;^{20}(2)$ the right of the committing authority to bill such individuals (and/or their families) for "care and maintenance" during institutionalization; ${ }^{21}$ (3) the limitations on the appointment of representative payees to manage the finances of certain patients, ${ }^{22}$ and (4) the interplay between state billing statutes and other federal laws suggesting that certain governmental benefits may not be "attached" by state authorities. ${ }^{23}$

Examination of these cases should reveal the extent to which economic rights issues have been considered carefully by the courts, the doctrinal principles (if any) that have been developed, the interplay (if any) between these cases and the other patients rights developments previously discussed, and the future paths which litigation and scholarship in this area can reasonably by expected to take.

\section{The Right of the Institutionalized to Control Their Own Assets}

Although the issue has not been litigated extensively, ${ }^{24}$ it appears to be relatively well settled that institutionalized mentally disabled persons cannot be deprived of the right to control their own assets absent a finding of incompetency consistent with rudimentary due process safeguards. ${ }^{23}$

${ }^{19}$ See, e.g., Brooks, supra note 4; Brant, supra note 4.

${ }^{20}$ See Part II, infra.

${ }^{21}$ See Part III, infra.

${ }_{22}^{2}$ See Part IV, infra.

${ }^{23}$ See Part V, infra.

${ }^{24}$ Cf. Jackson v. Indiana, 406 U.S. 715,737 (1972) ("Considering the number of persons affected, it is perhaps remarkable that the substantive constitutional limitations on [the civil commitment] power have not been more frequently litigated") (footnotes omitted).

In the otherwise-exhaustive and seminal 2300-page, three volume set of reference books published in 1979 by the Practising Law Institute and the Mental Health Law Project (MHLP), there is thus virtually no mention of economic rights of patients. See 1-3 Friedman, ed., LEGAL RIGHTS OF MENTALLY DISABLED PERSONS (P.L.I. 1979). And, in the just-published, similarly-exhaustive two volume set of reference books - published by the MHLP for the National Association of Protection and Advocacy Systemsthere is but one brief three-page note as to issues involving cost of care of institutionalization. See 2 MHLP, eds., PROTECTION AND ADVOCACY FOR PEOPLE WHO ARE LABELLED MENTALLY ILL 597 (1987).

${ }^{25}$ See, e.g., Vecchione v. Wohlgemuth, 377 F. Supp. 1361 (E.D. Pa. 1974), further proceedings 426 F. Supp 1297 (E.D. Pa. 1977), affd 558 F. 2d 150 (3 Cir. 1977), cert. den. 434 U.S. 943 (1977); McAuliffe v. Carlson, 377 F. Supp. 896 (D. Conn. 1974), suppl. 386 F. Supp. 1245 (D. Conn. 1975), rev'd on other gds. 520 F. 2 d 1305 (2 Cir. 1975), cert. den. 427 U.S. 911 (1976). See also, Board of Chosen Freeholders v. Connell, No. 83870 (N.J., Hudson City. Ct., Dec. 2, 1975) (county court vacated order which would have attached, for care and maintenance, all income of county hospital patients in excess of $\$ 25$ per month, and ordered individual hearings on the appropriateness of such assessments), discussed in "Right to Work," supra note 14, at 338 n.183.

On the other hand, many states with "Patients' Bills of Rights" include statutory provisions granting 
In the lead case of Vecchione v. Wohlgemuth, ${ }^{26}$ the district court was faced with the question of a Pennsylvania statutory scheme ${ }^{27}$ which enabled the state to summarily ${ }^{28}$ seize and control assets and property of certain ${ }^{29}$ mental patients, and then apply portions of those assets to cover the costs of the patients' care and maintenance while institutionalized. ${ }^{30}$

After finding that the division in the statutory scheme ${ }^{31}$ violated the equal protection clause (in that it was "irrational, arbitrary and . . . wholly unrelated to any purpose of the law in which the classification is made"), ${ }^{32}$ the court turned to plaintiff's procedural due process arguments. Preliminarily, it noted that the defendants (state officials) conceded that "mental patients are, barring an adjudication of incompetency, capable of managing their financial affairs," ", and that apparently-uncontested expert testimony concluded that "depriving mental patients of any control and responsibility over their own funds

\footnotetext{
institutionalized mentally disabled persons the right to control and to manage their own personal property and money. See, e.g., Mich Stat. Ann. $\$ 14.800$ (730) (3), (4) (1980) (except where denial is "essential in order to prevent the [patient] from unreasonably and significantly dissipating his assets," a patient "is entitled to easy access to the money in his account and to spend or otherwise use the money as he chooses'). See Beis, MENTAL HEALTH AND THE LAW 183-184 (1984). For an overview of all statutes, see Lyon, Levine \& Zusman, Patients' Bills of Rights: A Survey of State Statutes, 6 MENT. DIS. L. RPTR. 185 (1982), and LyonLevine, Levine \& Zusman, Developments in Patients' Bill of Rights Since the Mental Health Systems Act, 9 MENT. \& PHYS. DIS. L. RPTR. 146 (1985).

26377 F. Supp. 1361 (E.D. Pa. 1974), further proceedings 426 F. Supp. 1297 (E.D. Pa. 1977), affd 558 F. 2d

150 (3 Cir. 1977), cert. den. 434 U.S. 943 (1977).

${ }^{27} 50$ Pa. Stat. $\$ \$ 4424,4501$ (1966).

${ }^{28}$ See, e.g., $50 \mathrm{~Pa}$. Stat. $\$ 4424$ (1) (1966) ("The authorized agent... shall, without application to any court, take custody of, receive and manage ... any money or other personal property in [certain patients'] possession ... ") (emphasis added). See infra note 29, for a discussion of which patients were covered by this provision.
}

${ }^{29}$ Under the statutory scheme, two classes of patients were "created" for the purposes of due process safeguards: patients who had not been adjudicated incompetent (who were denied prior notice and hearing prior to seizure of their assets), and patients who had been adjudicated incompetent who were afforded such notice and hearing. Vecchione, 377 F. Supp. at 1363.

These classes were further separated on the basis of the amount of assets belonging to individual patients; if an incompetent patient had more than $\$ 2500$ in assets, a guardian would be appointed; if he had less than that amount, however, the failure to provide for notice and hearing meant that such patients "generally ha[d] no guardian or court to protect their assets." Id.

${ }^{30}$ See generally Part III, infra.

${ }^{31}$ See supra note 29.

${ }^{32}$ Vecchione, 377 F. Supp. at 1369. The court noted that the state could point to "no rational basis, not even revenue raising," id. at 1368, to justify the classification, which it characterized as "counter-productive and internally inconsistent with the goals of the [Mental Health Procedures] Act" and as being "arbitrary and Capricious." Id. Cf. e.g., Mernitz, Private Responsibility for the Costs of Care in Public Mental Institutions, 36 IND.L.J. 443, 444 (1961) ("[U]p-to-date procedures for the determination and enforcement of private responsibility can greatly enhance attempts to secure substantial revenues from institutionalized persons or their families.")

In light of its finding that the state law did not meet the minimum rationality test of the equal protection clause, the Vecchione court found it unnecessary to consider whether "fundamental rights and/or suspect classifications require a strict scrutiny test in this case. Id. at 1369 n.11. Cf. City of Cleburne, Tex. v. Cleburne Living Center, 105 S. Ct. 3249 (1985) (applying rational basis test to case involving mentally retarded individuals).

${ }^{33}$ Vecchione, 377 F. Supp. at 1367 (quoting from Partial Transcript, at 58). 
would tend to prolong a person's stay in a mental hospital, while giving them such control and responsibility is therapeutic." ${ }^{34}$

With this backdrop, the court found the statutory sections in question unconstitutional in that they failed to provide appropriate procedural due process safeguards. ${ }^{35}$ The income and governmental benefits" "intercepted and appropriated" by defendants were matters of "statutory entitlement to plaintiff," and thus to be treated as property entitled to constitutional protection under the due process clause. ${ }^{37}$

This analysis was further buttressed by analogy to a Second Circuit case which had found that a state's failure to provide adequate notice prior to the appointment of a committee to disburse a patient's assets was unconstitution$\mathrm{al}^{38}$ "where a state "does not even provide a judicial hearing, let alone notice thereof $[, a]$ fortiori the practice . . . must be set aside as violative of the Due Process Clause." ${ }^{\prime 39}$

The court specifically rejected defendants' argument in support of the practice in question: that there is often an immediate threat of "destruction, loss or mismanagement . . . by this type of plaintiff." ${ }^{20}$ First, even if this practice was "generally justifiable under the facts," the statutes in question were overly broad, ${ }^{41}$ and, in some cases, irrebuttable. ${ }^{42}$

Second, and, in the court's view, more fundamentally, the factual underpinning of this argument - that mental patients are "presumptively incapable of handling their own funds [-] has been stripped by the record in this case. ${ }^{943}$ As the court had rejected defendants' hypothesis that mental patients may be presumed less competent to handle their own assets than the public at large, "there is no legitimate justification for the [defendants'] interference with plaintiff's custody and control of her property without an adjudication that she was incompetent to manage it. ${ }^{44}$

${ }^{34}$ Id. at 1.367 , and see cited sources.

See also, e.g., Koe v. Califano, 573 F. 2d 761, 763 n.5 (2 Cir. 1978):

SSI payments make possible the purchase of items essential to any human existence transcending bare subsistence. The loss of such payments imposes a readily understandable burden; less obvious but perhaps no less significant are the uncertainty and feelings of rejection inflicted by the continuous threat of deprivation on those who have so little and are mentally ill.

35 Vecchione, 377 F. Supp. at 1370, citing, inter alia, Fuentes v. Shevin, 407 U.S. 67,82 (1972).

${ }^{36}$ Defendants had summarily seized social security benefits of plaintiff's "without notice and hearing or explanation." Id. at 1365 . Plaintiff argued that, absent a knowing voluntary and intelligent assignment of such benefits, they were "insulated from claims of creditors, including the state" under both federal statute (42 U.S.C. $\$ 407$ (1970)) and case law (Philpott v. Essex County Welfare Bd., 409 U.S. 413 (1973)). Id. at 1366.

See Woodall v. Bartolino, Civil No. 85-1781(MTB) (D.N.J., Oct. 24, 1985), discussed in Part V, infra, for a general discussion of the question of the application of $\$ 407$ and Philpott to institutionalized mental patients.

${ }^{37}$ Vecchione, 377 F. Supp. at 1370, citing, inter alia, Goldberg v. Kelly, 397 U.S. 254, 262 (1970).

${ }^{38}$ Dale v. Hahn, 486 F. 2d 76 (2 Cir. 1973).

${ }^{39}$ Vecchione, 377 F. Supp. at 1371 .

40Id.

$41 \mathrm{Id}$.

42Id. n.14.

43Id. at 1372.

${ }_{44}^{4}$ For a general discussion of post-Vecchione procedures, see Tartaglia v. Com., Dept. of Public Welfare, 416 A. 2d 608, 612 (Pa. Cmwlth. Ct. 1980). Vecchione was followed in a parallel case involving Veterans' 
In a different factual context, ${ }^{45}$ another federal district court similarly struck down as unconstitutional a Connecticut statute which authorized the state finance commissioner to serve as conservator of funds of any mentally ill 'person with property or annual income of less than $\$ 5000$ committed or admitted to a state mental institution. ${ }^{46}$ As such hospital admission "does not support even a presumption that a mental patient is incompetent," ${ }^{47}$ the state's irrebuttable presumption of incompetency violated due process. ${ }^{48}$

Because the statute exempted persons with more than $\$ 5000$ in assets, it also violated the equal protection clause as it was "irrational to think that all or even most state mental patients without real property and income of more than $\$ 5000.00$ are incompetent. ${ }^{.49}$

\section{Right to Bill for "Care and Maintenance"}

\section{(A) Authority to Bill Patients}

The majority of involuntary civil commitment statutes require that the institutionalized mentally disabled person (or a legally responsible relative) pay for some percentage ${ }^{50}$ of the person's cost of institutionalization..$^{51}$ These statutes ${ }^{52}$ variously stipulate payment for, inter alia, "care, transportation and treat-

Administration benefits in In re Grcich, 492 Pa. 210, 423 A. 2d 347, 350 n.7 (Sup. Ct. 1980), cert. den. 450 U.S. 997 (1981).

The practical impact of Vecchione has been questioned in Burgdorf, ed., THE LEGAL RIGHTS OF HANDICAPPED PERSONS 562 (Paul R. Brookes 1980) (all of the first 179 due process hearings held in conformity with Vecchione decree led to declarations that patients were incompetent to handle their own property). For the appellate decision in one such case, see Matter of Caine, 490 Pa. 24, 415 A. 2d 13, 14 n.2 (Sup. Ct. 1980).

${ }^{45} M c$ Auliffe, supra, was brought by a patient who was transferred to a mental health facility from a city correctional center, where he had been serving a term of imprisonment following a felony conviction. $377 \mathrm{~F}$. Supp. at 898.

${ }^{46} \mathrm{Id}$. at 904. Plaintiff had argued that this statute deprived him of his "civil rights to enter and enforce contracts, settle and enforce obligations or make gifts of his property without the essential safeguards of notice and an opportunity to be heard on this issue of his competency." Id.

${ }^{47} I d$, citing Winters v. Miller, 446 F. 2d 65, 68 (2 Cir. 1971), applied specifically in Connecticut in Logan $\gamma$. Arafeh, 346 F. Supp. 1265, 1269-1270 (D. Conn. 1972).

48. Id. at 905 .

${ }^{49} I d$. Subsequently, the Second Circuit reversed on Eleventh Amendment grounds a supplemental order which had directed defendants to return certain property to plaintiff. See 520 F. 2d 1305 (2 Cir. 1975), rev'g 386 F. Supp. 1245 (D. Conn, 1975).

${ }^{50}$ See Ross, Commitment of the Mentally Ill: Problems of Law and Policy, 57 MICH. L. REV. 945, 946 (1959); Mernitz, supra note 32, at 466, and id. n.82 (only $10 \%$ of actual costs recovered).

"Developments in the Law-Civil Commitment, 87 HARV. L. REV. 1190, 1365 (1974) ("Developments"), and see, for a sampling of statutes, $i d$. n.221. See, for a detailed description of two contrasting acts (Virginia's and West Virginia's), Note, West Virginia's Reimbursement Statute: The Hidden Costs of Institutionaliza. tion, 85 W. VA. L. REV. 121, 129-133 (1982), and see, for a thorough historical overview, Mernitz, supra note 32.

${ }^{52}$ For an analysis of why these statutes generally may increase in importance in the near future (because of expected diminution of alternative federal funding sources and a "change in public attitude toward the economically disadvantaged"), see Note, 85 W. VA. L. REV., supra note 51, at 134. 
ment," "care and treatment," "s4 "service and treatment,"ss and "examination, maintenance, and treatment." $"$ s6

In addition, the payment responsibility statutes are often unclear as to the employment of a mechanism by which a patient's precise liability can be assessed ${ }^{57}$ various statutes and regulations mitigate assessments based upon "clinical reasons," "ss "substantial hardship," "99 "ability to provide for payment," being "reasonably able to pay,"61 or having "sufficient financial ability." Statutes variously incorporate specific pay schedules ${ }^{63}$ and mandate that state mental health departments adopt regulations to set up such standards. ${ }^{64}$

While such statutes have been challenged on a variety of grounds, they have been regularly upheld against substantive attack; ${ }^{65}$ however, in some instances, courts have struck down provisions for violations of procedural due process rights. ${ }^{66}$

Thus, courts have uniformly rejected statutory challenges which have raised the argument that the distinction between mental patients (who must pay) and prisoners (who are not so billed) violates the equal protection clause of the Fourteenth Amendment, ${ }^{67}$ or that they impermissibly delegate legislative authority to state executive agencies. ${ }^{68}$

One the other hand, courts have examined carefully the way such statutes are invoked, and have both struck down provisions which failed to provide for

${ }^{33}$ Alaska Stat. $\$ 47.30 .910$ (a) (1985).

${ }^{34} \mathrm{Vt}$. Stat. Ann., tit. 18, $\$ 8101$ (1985 Supp.). Under the Vermont law, the patient (or a legally responsible relative) must pay or contribute to the payment "in such manner and proportion as the commissioner [of Mental Health] shall determine to be within [his] ability to pay").

${ }_{55}$ Wyo. Stat. Ann. \$25-10-202 (a) (1985).

56 Ariz. Rev. Stat. \$36-545.01 (1974).

57"Developments," supra note 51, at 1366.

$5855 \mathrm{~Pa}$. Code $\$ 4305.7$ (b) (3) (1985). Abatement will be granted under this section only where (1) the imposition of the maximum liability would be likely to "negate the effectiveness of treatment, or prohibit the client's entry into treatment," and (2) the failure to provide such treatment "would result in serious harm to the client's welfare or in greater cost to this Commonwealth due to deterioration of the client's condition." See generally, Faix v. Com. Dept. of Public Welfare, 499 A. 2d 411 (Pa. Cmwlth. Ct. 1985).

${ }^{59}$ See 55 Pa. Code $\$ 4305.7$ (2) (1985), discussed in Faix, supra.

${ }^{60}$ See, e.g., Alaska Stat. $\S 47.30 .910$ (a) (1985).

6iSee, e.g. D.C. Code Ann. \$21-586 (b) (1981).

${ }^{62}$ See, e.g., Utah Code Ann. §64-7-6 (1978).

${ }^{63}$ See, e.g., Minn. Stat. Ann. \$246.511 (1982).

${ }^{64}$ See, e.g., Wyo. Stat. Ann. $\$ 25-10-202$ (a) (1985).

For a philosophical inquiry into the relationship between the reimbursement mechanisms and prevailing public attitudes toward the mentally ill, see Mernitz, supra note 32, at 481-482.

${ }^{65}$ See, e.g., infra notes 67-68.

${ }_{66}^{6}$ See, e.g., infra notes 69-71. But see, Hospital Services, Inc. v. Farnsworth, 393 N.W. 2d 446 (N.Dak. Sup. Ct. 1986) (statute of limitations inapplicable in suit against former patient); see generally on statute of limitation questions in cases involving patients' estates, Part III(C), infra.

${ }^{67}$ Faye v. Stapley, 607 F. 2d 858, 863 (9 Cir. 1979), collecting cases. Cf. Department of Mental Hygiene v. Kirchner, 60 Cal. 2d 716, 36 Cal. Rptr. 488, 388 P. 2d 720 (Sup. Ct. 1964), vacated 380 U.S. 194 (1965), on remand 62 Cal. 2d 586, 43 Cal. Rptr. 329, 400 P. 2 d 321 (Sup. Ct. 1965) (challenge to imposition of liability on certain relatives of institutionalized patients upheld on state constitutional grounds).

${ }^{68}$ See, e.g., State ex rel. Macey v. Johnson, 296 P. 2d 588, 589-590 (Idaho Sup. Ct. 1931) (collecting earlier cases). 
adequate personal notice ${ }^{69}$ or for a hearing ${ }^{70}$ for institutionalized persons who had never been declared legally incompetent, and have ordered trials to determine whether a patient actually received notice of a petition seeking to require maintenance payments."

Courts have also considered whether such maintenance charges against patients may be sustained on an unjust enrichment theory. In a case where patients were committed illegally, ${ }^{72}$ the Wisconsin Supreme Court rejected that specific argument:

Because the [commitment] proceedings were not adequate to sustain a finding that the individuals were in need of care and treatment, regardless of the fact that they may have been in need of such care and treatment, there was no valid commitment order. Thus, the plaintiffs cannot be considered "committed" for any purpose, and they do not fall under the literal reading of [the care and maintenance statutel. ${ }^{73}$

Finally, a court has rejected the argument of a patient's guardian seeking to raise the question of the reasonableness of the charges assessed against his ward while a state hospital resident, in a state where he alleged that "reasonable value" wished to introduce evidence to show that profit-making private institutions were charging from 20 to $33 \%$ of the state's charges for providing "the same care and treatment that the public institution furnished," "76 this would not be a proper topic for inquiry at a maintenance hearing:

\footnotetext{
${ }^{69}$ Foundation for the Handicapped v. Dep't of Social and Health Services, 97 Wash 2d 691, 648 P, 2d 884, 887-888 (Sup. Ct. 1982); Duffy v. Dep't of Social and Health Services, 90 Wash 2d 673, 585 P. 2d 470 (Sup. Ct. 1978).

${ }^{70}$ McConaghley v. City of New York, 60 Misc. 2d 825, 304 N.Y.S. 2d 136, 137-138 (Civil Ct. 1969).

${ }^{71}$ Fayle, 607 F. $2 \mathrm{~d}$ at 862.

${ }^{72}$ See State ex rel. Memmel v. Mundy, 75 Wis. 2d 276, 249 N.W. $2 d 573$ (Sup. Ct. 1977), invalidating all Milwaukee County commitments during the relevant time period for violations of the patients right to counsel and right to jury trial.

${ }^{73}$ Jankowski v. Milwaukee County, 104 Wis. 2 d 431, 312 N.W. 2d 45, 48 (Sup. Ct. 1981). On the question of the "benefits" that plaintiffs may have received, the court made this observation:
}

Plaintiff makes this cogent argument in his petition for review before this court: "OF what value is a bed on a locked ward to a person illegally deprived of access to his/her own home? To a person who is not mentally ill, of what possible benefit is treatment such as psychotropic medication? And of what use is occupational therapy to one whose illegal commitment has prevented him/her from going to work? To presume that the services were of value to plaintiffs ignores the grossly defective procedures by which they were committed and the importance of the due process protections for fair and correct judicial determinations.

Id. n.5.

${ }^{74} \mathrm{Cal}$. Civil. Co. $\$ 38$ (1982). The statute in question, first enacted in 1872 , reads:

A person entirely without understanding has no power to make a contract of any kind, but he is liable for the reasonable value of things furnished to him necessary for his support or the support of his family.

(Emphasis added).

73In re Estate of Gridley, 32 Cal. App. 3d 268, 108 Cal. Rptr. 200 (Ct. App. 1973).

${ }^{76}$ Gridley, 108 Cal. Rptr. at 208. 
[I]f each person liable under the law as constitutionally applied were permitted to question the price of pills, nursing and psychiatric services, room and board, by adducing the testimony of an expert of his choice in separate actions for the recovery of charges, the situation would be chaotic. [Analogizing to the test ${ }^{77}$ employed in cases involving special assessment proceedings, "the] final decision ... is conclusive unless attacked on the ground of fraud or mistake. . . ."

If there is graft, fraud or gross inefficiency which is pushing up the actual costs of the services in question the matter is one to be rectified by governmental action prodded by a vigilant public... [T] charges determined in accordance with the statutory mandate should control, in the absence of evidence showing that the determination itself was erroneous because of some dereliction of duty by the officer computing them, or because he acted in an arbitrary or discriminatory manner. . . . ${ }^{78}$

\section{(B) Authority to Bill Relatives}

Most modern cases $^{79}$ have held that statutes imposing liability upon the estates of relatives of institutionalized mentally disabled persons for their care and maintenance are a legitimate exercise of legislative power. ${ }^{80}$ Courts have been willing, however, to consider "competition" between (or among) relatives and the impact of post-hospitalization divorce on liability in such circumstances. ${ }^{81}$

\section{(1) Upholding Authority}

Cases which uphold statutes imposing liability on relatives date to the Elizabethan Poor Laws of Great Britain ${ }^{82}$ and are generally based on the theory that such a law "merely recognizes the imperfect moral obligation [to support an institutionalized relative] and makes of it a legal one." ${ }^{33}$ The historical basis for such holdings is reflected in the words of a nineteenth century decision:

It can hardly be said that there is no moral duty whatever imposed upon a man, who has sufficient financial ability consistently with his duty to himself and to others, to supply the necessaries of life to a brother or sister who is unable to earn a livelihood in consequence of

${ }^{77}$ See Larsen $v$. San Francisco, 182 Cal. 1, 14, 186 P. 757, 763 (Sup. Ct. 1920).

${ }^{78}$ Gridley, 108 Cal. Rptr. at 208-209.

${ }^{79} \mathrm{For}$ an overview of earlier cases, see Annotation, Constitutionality of Statute Imposing Liability Upon

Estate or Relatives of Insane Person for His Support in Asylum, 20 A.L.R. 3d 363.

${ }^{B 0}$ See generally, Part III (B)(1), infra. This view is not unanimous, however. See, e.g., Department of Mental Hygiene v. Kirschner, 60 Cal. 2d 716, 388 P. 2d 720, 26 Cal. Rptr. 488 (Sup. Ct. 1964), vacated, 380 U.S. 194 (1965), on remand 62 Cal, 2d 586, 400 P. 2d 381, 43 Cal. Rptr. 329 (Sup. Ct. 1965), discussed at Part III (B)(2), infra.

${ }^{81}$ See Part 111 (B)(3), infra.

${ }^{82}$ See 43 Eliz. c.2 $\$ 7$ (1601), cited in Beach v. Gov't of the District of Columbia, 520 E. 2d 790, 792 n.4 (D.C.Cir. 1963). Most contemporaneous American statutes are "little more than a paraphrase of . . . the 
bodily infirmity, idiocy, lunacy, or other unavoidable cause ... The object of both the statute of Elizabeth and of our existing statute is to protect the public from loss occasioned by neglect of a moral or natural duty imposed on individuals, and to do this by transforming the imperfect moral duty into a statutory and legal liability. ${ }^{84}$

With this backdrop, most courts disposed quickly of constitutional challenges by patients' relatives. First, arguments based on state constitutional provisions requiring state support of such institutions were rejected on the theory that such sections did not mandate the provision of services to patients at the sole expense of the state ${ }^{85}$ Second, equal protection claims premised on both the state and federal constitutions ${ }^{86}$ arguing that patients' relatives were being doubly taxed have been denied as "specious" because of the "special relationship" between the patient and his relative. ${ }^{87}$ Third, challenges based on the theory that liability laws constituted special or class legislation (since they differentiated between patients confined in state hospitals and those housed elsewhere) have similarly been turned back on the theory that "the distinction between the helpless and those able to help themselves is a natural one [that] pervades the laws of all civilized countries." ${ }^{88}$ Also, arguments premised on an improper delegation theory ${ }^{89}$ have been rejected where courts have found that the statutory provisions in question contained reasonable standards to properly guide the administrator charged with their effectuation. ${ }^{90}$

Also, in upholding another liability statute in face of a due process challenge, the District of Columbia Court of Appeals limited the relative's liability only as to that date on which hospital authorities first demanded contributions from him (as opposed to the time, soon after her commitment, when the patient's own assets were depleted). ${ }^{91}$ On the other hand, an Indiana intermediate appeals court ruled that a change in the "responsible relatives" statute did not abrogate a father's responsibility for his son's care and maintenance prior to the effective date of the amendment. ${ }^{92}$

\footnotetext{
${ }^{84}$ People v. Hill, 163 Ill. 186, 46 N.E. 796, 798 (Sup. Ct. 1896), as quoted in Beach, 320 F. 2d at 792-793 (footnote omitted). See also, e.g., In re Idleman's Commitment, 146 Or. 13, 27 P. 2 d 305 (Sup. Ct. 1933); Commonwealth v. Zommick, 362 Pa. 299, 66 A: 2d 237 (Sup. Ct. 1949).

${ }^{83}$ State Rev. Div. of Dept. of Treas. v. Estate of Raseman, 18 Mich. App. 91, 170 N.W. 2d 503, 506 (Ct. App. 1969) (Raseman); see also, e.g., State v. Kiesewetter, 37 Ohio St. 546 (Sup. Ct. 1882); Kaiser v. State, 80 Kan. 364, 102 P. 454 (Sup. Ct. 1909), construing similar provisions; see also Department of Public Welfare $y$. Haas, 15 Ill. 2d 204, 154 N.E. 2d 265, 270-271 (Sup. Ct. 1958) (rejecting challenge based on state's constitutional provision mandating a "thorough and efficient" education); see generally, Levine v. Institutions and Agencies Dept. of N.J., 84 N.J. 234, 418 A. 2 d 229 (Sup. Ct. 1980), criticized as "unfortunate[]" in Note, 85 W.VA. L. REV., supra note 51, at 126. See also Levine, 84 N.J. at 268, 269 (Pashman, J., dissenting) (criticizing the majority for having "completely abdicated its fundamental responsibility of constitutional judicial review," and for a result which "diminishes the meaning of our common humanity").

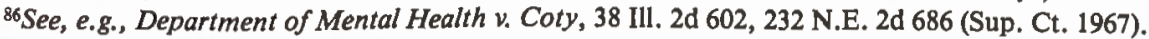

${ }^{87}$ Raseman, 170 N.W. 2d at 506-507.

${ }^{88}$ In re Yturburru's Estate, 134 Cal. 567, 66 P. 729 (Sup. Ct. 1901). See also State v. Troxler, 202 Ind. 268, 173 N.E. 321 (Sup. Ct. 1930); Wigington v. State Home \& Training School, 486 P. 2d 417, 420 (Colo. Sup. Ct. 1971).
}

${ }^{89}$ See Part III(D), infra.

${ }^{90}$ Kough v. Hoehler, 413 Ill. 409, 109 N.E. 2d 177 (Sup. Ct. 1952).

${ }^{21}$ Beach, $320 \mathrm{~F} .2 \mathrm{~d}$ at 794.

${ }^{92}$ Estate of Hinds v. State, Mental Health Commissioner, 390 N.E. 2d 172, 173-174 (Ind. Ct. App. 1979). 


\section{(2) Denying Authority}

On the other hand, in Department of Mental Hygiene v. Kirchner, ${ }^{93}$ the California Supreme Court has held that a state statute ${ }^{94}$ imposing liability upon a daughter for the care and maintenance of her mother in a state psychiatric institution violated the equal protection clause of the constitution in that it selected one class of persons for a "species of taxation [with] no rational basis support[ing] such classification."'9s

In examining the issues, the court studied the relevant historical background, ${ }^{96}$ and carefully distinguished cases upholding spousal liability" in such cases, "the basic obligation and relevant status of the husband arose from the marriage contract to which he was a consenting party."198 Also, the court considered what it characterized as "the social evolution which has been developing during the past half century," which has brought "expanded recognition of the parens patriae principle ... and other social responsibilities ... and divers other public welfare programs to which all citizens are contributing through presumptively duly apportioned taxes. 999

Because the state Supreme Court did not clarify whether its ruling was premised on the equal protection clause of the federal or state constitution, the United States Supreme Court vacated and remanded for further proceedings. ${ }^{100}$ On remand, the state Supreme Court stated that, while the cognate state and federal provisions "provide generally equivalent but independent protections," it made its determination of unconstitutionality "by our construction and appli-

\footnotetext{
${ }_{93}^{90}$ Cal. 2d 716, 36 Cal. Rptr. 488, 388 P. 2d 720 (Sup. Ct. 1964).

${ }^{94} \mathrm{Cal}$. Welfare \& Instns. Co. $\$ 6650$ (1965) ("The husband, wife, father, mother, or children of a mentally ill person... shall be liable for his care, support, and maintenance in a state institution of which he is an inmate..."

${ }^{95}$ Kirchner, 36 Cal. Rptr. at 492 . The statutory section in question has been repealed, see Cal. Stats. 1967, c.1667, p. $4107, \$ 36.5$, and has since been replaced by Cal. Welfare \& Instns. Co. \$7275 (1984), which contains nearly-identical language. Later developments in Kirchner are discussed infra, at text accompanying notes 104-108.

Although the party who litigated the Kirchner case was the administratrix of the daughter's estate, see generally, Part III (C), infra, the case is being discussed in connection with relatives' liability since that is by far the most significant aspect of the case for further analysis.
}

${ }_{96}$ Id. at 489 n.4.

${ }^{97}$ Id. at 490, discussing Guardianship of Thrasher, 105 Cal. App. 2d 768, 234 P. 2d 230, 235-236 (Ct. App. 1951).

.98 Kirchner, $36 \mathrm{Cal}$. Rptr. at 490 (emphasis in original). The court also relied on its prior decision in Department of Mental Health v. Hawley, 59 Cal. 2d 247, 28 Cal. Rptr. 718, 379 P. 2 d 22 (Sup. Ct. 1963), see infra note 144 , holding that recovery could not be had as against a father of a criminally-committed patient. For equal protection purposes, this decision was "dispositive" of the case before it, the Kirchner court found. Id.

99Id. at 491.

Kirchner is criticized rigorously in Comment, Compulsory Contribution to Support of State Mental Patients Held Deprivation of Equal Protection, 39 N.Y.U. L. REV. 858, 863 (1964); see also, In re Dudley, $239 \mathrm{Cal}$. App. 2d 401, 48 Cal. Rptr. 790, 794 n.8 (D. Ct. App. 1966) (listing commentary criticizing Kirschner).

${ }^{100}$ Department of Mental Hygiene of California v. Kirchner, 380 U.S. 194 (1965).

${ }^{101}$ Department of Mental Hygiene v. Kirchner, 62 Cal. 3d 586, 43 Cal. Rptr. 329, 330, 400 P. 2 d 321 (Sup. Ct. 1965). See generally "Last Frontier," supra note 4. 
cation of California law" and not "by compulsion of the Fourteenth Amendment." 102

Kirchner was followed ${ }^{103}$ in a subsequent case involving the liability of a parent of an institutionalized mentally ill adult, ${ }^{104}$ and was distinguished where a separate statutory scheme controlled the imposition of parental liability for the care and maintenance of a mentally incompetent adult daughter in a state facility for the retarded. ${ }^{105}$ Elsewhere, the California courts have declined to extend its holding to cases involving spousal liability ${ }^{106}$ or the obligation of a parent to a minor child. ${ }^{107}$

Finally, much of the precedential persuasiveness of Kirchner was diminished by a California Supreme Court case upholding a state law requiring adult children to reimburse the state for certain welfare aid made to their non-institutionalized parents, ${ }^{108}$ over the vigorous dissent of two judges (who had joined in Kirchner) that the decision effectively overruled the Kirchner holding. ${ }^{109}$

Also, courts have looked carefully at the claims by relatives that their procedural due process rights have been violated by the means by which such costs of maintenance were determined. Thus, the Michigan Supreme Court struck down a state law ${ }^{110}$ because it failed to (1) provide for notice of hearing on the relatives' request for a new determination of liability, ${ }^{111}$ (2) designate a hearing officer or examiner to make a determination as to liability "either from evidence or the submitted information,"12 or (3) provide legislative standards or guidelines for the appropriate exercise of rulemaking power. ${ }^{113}$

${ }^{102} I d$.

${ }^{103}$ See aiso Hospital Services, Inc. v. Brooks, 229 N.W. 2d 69, 72 (N. Dak. Sup. Ct. 1975), generally following Kirchner in deciaring unconstitutional state statute requiring children to pay for parents' care at state hospital.

${ }^{104}$ Department of Mental Hygiene v. Bank of America N.T. \& S.A., 3 Cal. App. 3d 949, 83 Cal. Rptr. 559 (Ct. App. 1970).

${ }^{109}$ Dudley, supra. See also, In re Estate of Preston, 243 Cal. App. 2d 803, 52 Cal. Rptr. 790 (D. Ct. App. 1966), distinguishing Kirchner in case involving guardian of incompetent mentally retarded institutionalized ward with substantial assets.

${ }^{106}$ Depariment of Mental Hygiene v. O'Connor, 246 Cal. App. 2d 24, 54 Cal. Rptr. 432, 434 (D. Ct. App. 1966); Department of Mental Hygiene v. Kolts, 247 Cal. App. 2d 154, 55 Cal. Rptr. 437, 441 (Ct. App. 1966) ("It is clear that .... Kirchner refused to equate the basic obligation of the husband arising out of the marriage contract with an adult daughter's obligation to support a parent").

${ }^{107}$ See County of Alameda v. Kaiser, 238 Cal. App. 2d 815, 48 Cal. Rptr. 343 (D. Ct. App. 1966) (not denial of equal protection to impose upon mother liability to county for medical services rendered to minor son in county hospital), and County of Alameda v. Espinoza, 243 Cal. App. 2d 534, 52 Cal. Rptr. 480 (D. Ct. App. 1966) (upholding parent's statutory obligation to support minor child committed to county institution).

${ }^{108}$ Swoap v. Superior Court of Sacramento County, 10 Cal. 3d 490, 111 Cal. Rptr. 136, 516 P. 2 d 840 (Sup. Ct. 1973).

${ }^{109}$ See id., $111 \mathrm{Cal}$. Rptr. at 160 (Tobriner, J., dissenting). The impact of Swoap on the holding in Kirchner is considered carefully in Hospital Services, Inc., 229 N.W. 2 d at 72-75.

"10Miller v. State, Dep't of Treas. (Rev. Div.), 385 Mich. 296, 188 N.W. 2d 795 (Sup. Ct. 1971 ).

${ }^{11}$ Cf. Powell v. Comm. Dept. of Public Welfare, 455 A. 2d 1287, 1289 (Pa. Cmwlth. Ct. 1983) (appellant has burden of proving right to abatement or modification of assessment of liability).

112Miller, 188 N.W. 2d at 798. See also, e.g., In re McVey's Estate, 170 Neb. 362, 102 N.W. 2d 632,634 (Sup. Ct. 1960) (requiring investigation and determination of relative's ability to pay).

${ }_{113}$ Miller, supra. The court noted that the state statute contained "no legal requirements or provisions to be 


\section{(3) Other Issues}

Other cases have considered subsidiary issues arising out of the impact of divorce proceedings both as to allocation of liability as between potentiallyresponsible relatives and as to spousal liability. ${ }^{114}$ In a New York case involving an institutionalized juvenile, where separate hearings were held in an effort to assess liability of the juvenile's divorced parents and maternal grandfather, ${ }^{15}$ the court ordered an "integrated proceeding" with notice to all parties, along with an opportunity for "mutual cross-examination." "16

Elsewhere, in an ingenious, but ultimately unsuccessful attempt to avoid liability, a patient's wife argued that, while she had grounds to divorce her husband prior to his commitment, she declined to initiate such proceedings because of her religious beliefs, and that, thus, the state relatives' liability statute amounted to a constitutionally-impermissible preference given to persons whose choice of religion permits divorce. ${ }^{117}$ The court rejected this argument as "clearly without merit," noting that the statutes "contain nothing which even remotely purports to impair religious freedom."118

\section{(C) Authority to Bill Estate}

As with claims against relatives, ${ }^{119}$ most cases have held that statutes imposing liability on the estates of institutionalized mentally disabled persons are valid exercises of legislative power, although at least one recent case has limited the scope of liability so that the survivors" "legitimate needs and comforts" would still be provided. ${ }^{120}$

An early case rejected an estate administrator's argument that the state was estopped from making demands on the estate because it had originally paid a share of the patient's costs when hospitalized: when the state "acts of its own volition, in response to the dictates of humanity, in the performance of a governmental duty now recognized as resting upon a modern state and for the good of the individual concerned," the elements of estoppel are not present. ${ }^{121}$

applied to the facts by the Department of Revenue in redetermining liability" and operated "with an uncontrolled discretion." Id.

Miller was a sharply-split 4-3 decision. In a lengthy dissent, Judge Brennan argued that the act satisfied minimal constitutional requirements "since it produces generally fair results and establishes a classification which bears a reasonable relationship to [its] object ..." 188 N.W. 2 d at 798,811 .

${ }^{14}$ See, e.g., State, Dept. of Mental Health \& Mental Retardation v. Wiedemann, 1 Ohio App. 3d 27, 437 N.E. 2d 1212, 1214-1215 (Ct. App. 1980) (where parents are both obligated to pay for institutional care of minor child, question of what share each of two divorced parents should pay is matter to be determined from divorce decree).

113 In the state statute then operative, the juvenile's father, mother and grandparents were all potentially responsible for support depending on their "comparative resources and equities." See Department of Welfare of City of New York v. Mallory, 20 A.D. 2d 884, 248 N.Y.S. 2d 805, 806 (App. Div. 1964), construing N.Y. Family Ct. Act $\$ 415$ (1983).

116Id.

"Department of Mental Health v. Warmbir, 37 Ill. 2d 267, 226 N.E. 2d 4, 5 (Sup. Ct. 1967).

118 Id. at 5,6 .

${ }^{119}$ See Part III(B), supra.

${ }^{120}$ Chill v. Mississippi Hospital Reimbursement Commission, 429 So. 2d 574, 586 (Miss. Sup. Ct. 1983).

${ }_{121}$ State v. Romme, 93 Conn. 571, 107 A. 519, 520 (Sup. Ct. Err. 1919). 
More recently, a South Carolina court held that the state had a valid claim against an estate's administrator, finding that care and maintenance in a state facility is not "unconditional charity but is based upon expectations of future reimbursement if the circumstances should thereafter permit."122

In Chill v. Mississippi Hospital Reimbursement Commission, ${ }^{123}$ the Mississippi Supreme Court found that the state's power to require reimbursement for care and treatment was "carefully limited," especially where the patient was committed involuntarily. ${ }^{124}$ Concluded the court:

As long as the State of Mississippi limits such commitments to those, and only those, truly in need of mental treatment, and as long as the state confines its mental patients under humane conditions and provides minimally adequate care and treatment, it is not unreasonable to require the patient, his family or his estate to pay at least a part of the bill. ${ }^{125}$

The court considered carefully the administrator's argument that, because the patient's initial commitment in 1953 violated his procedural due process rights, the state's current reimbursement claim cannot withstand due process scrutiny. ${ }^{126}$ After examining the past decade's "explosion of litigation" regarding the substantive and procedural due process rights of mentally disabled persons, the court conceded that it was "[w]ithout doubt [that the patient] was denied both substantive and procedural due process at the time of his [1953] commitment." 127

In the context of the proceedings before the court, however, this merely meant that the state agency was required to "prove [the] fact anew" that the patient "was in fact mentally ill and in substantial need of institutionalization," proof that was offered at the hearing below. Procedural due process would be satisfied if "the estate [were] afforded a reasonably adequate adversary hearing before an impartial judicial officer at which time [the state agency] had to prove by a preponderance of the evidence each factual point requisite to the substantive validity of its reimbursement claim." ${ }^{28}$

The court noted, however, that, under state statute, reimbursement claims could not be asserted "beyond ability to pay," and that the "plight of relatives or dependents must be considered in determining [such] ability." ${ }^{22}$ Under this

${ }^{122}$ Minter v. State Dep't of Mental Heâlth, 187 S.E. 2d 890, 893 (S.C. Sup. Ct. 1972). See also In re Estate of Klimko, 111 Misc. 2d 411, 444 N.Y.S. 2d 391 (Surrogate's Ct. 1981) (state not precluded by its reduction or waiver of fees from seeking retroactive reimbursement from estate, where claim concededly reflected charges for care received).

123429 So. 2 d 574 (Miss. Sup. Ct. 1983).

${ }^{124} \mathrm{Id}$. at $576,579$.

${ }^{123} \mathrm{Id}$. See also id. at 579-580, surveying other jurisdictions where similar powers have been upheld, and id. at 581-582, collecting cases from other jurisdictions specifically allowing for recovery of similar expenses from an estate even where the patient was committed prior to the passage of the estate reimbursement act.

${ }^{126}$ Chill, 429 So. $2 \mathrm{~d}$ at 582.

${ }^{127}$ Id. at 584 .

${ }^{128}$ Id. at 584 . After examining the evidence, the court concluded that the estate's administrator "received full procedural due process." Id. at 585.

${ }^{129} I d$, at 586, citing Miss. Code Ann. \$41-7-79 (1972). See also, Wigington v. State Home and Training 
legislative policy, trial courts must allow for the provision of "the legitimate needs and comforts of the patient and his or her dependents or surviving relatives" as an "absolute priority" over state claims. ${ }^{130}$

Other cases construing similar claims have dealt with various procedural and substantive aspects of applicable estate law. Thus, where a state initially failed to seek full reimbursement for a patient's care, that failure did not serve as a waiver of the state's right to seek full reimbursement from the estate after the patient's death. ${ }^{131}$ Elsewhere, courts have split on the question of the applicability of statutes of limitations and statutes of nonclaims to claims filed by state entities against estates ${ }^{132}$ and have generally held that a state can reach and recover from a trust of which an institutionalized person is a beneficiary. ${ }^{133}$

Finally, at least one court has considered the question of priority of liens in a case involving a piece of land owned by an incompetent patient in a state mental health facility. ${ }^{134}$ There, the state supreme court remanded a lower court decision establishing lien priority because it was clear that the patient had the ability to pay each of them in full. ${ }^{13 s}$

\section{(D) Authority to Bill "Criminally Confined" Patients for Their Care and Maintenance}

To some extent, special rules have developed in the analysis of cases of patients whose institutionalization was originally precipitated by some involvement with the criminal justice system: either pursuant to a finding of incompetency to stand trial (IST), to a determination of "not guilty by reason of insanity" (NGRI), or following either arrest or apprehension on criminal charges. ${ }^{136}$

School, 486 P. 2d 417, 421 (Colo. Sup. Ct. 1971) (reversing judgment because of a "nearly . . . complete vacuum" as to whether estate was "able to pay" during relevant periods).

${ }^{130}$ Id. at 586-587. Cf. State v. Morris, 303 S.W. 2d 802, 803 (Tex. Ct. Civ. App. 1957) (where patient inherited $\$ 10,000$ twenty years after his initial commitment, court denied state claim for reimbursement of prior services and treatment rendered, but indicated that money could be seized only to pay for treatment rendered after the date of the inheritance).

${ }^{13 !}$ Gass v. State Department of Mental Hygiene, 23 A.D. 2d 329, 255 N.Y.S. 2d 314 (App. Div. 1965). See also In re Estate of Gnerre, 87 Misc. 2d 700, 386 N.Y.S. 2d 763 (Surrogate's Ct. 1976) (no waiver where state previously accepted money at a lesser rate of payment).

${ }^{132}$ Compare State v. Stone, 271 S.W. 2 d 741 (Tex. Ct. Civ. App. 1954) (statute of limitations inapplicable), and see also Gnerre, 386 N.Y.S. 2d at 765, to State, Dept. of Mental Health \& Mental Retardation v. Koblentz, 2 Ohio App. 3d 278, 441 N.E, 2d 820 (Ct. App. 1981) (statute of limitations applicable), and State ex rel. Griffin Mem. Hosp. v. Reed, 493 P. 2d 815, 818 (Okla. Sup. Ct. 1972) (statute of nonclaims applicable).

Statutes of nonclaims are discussed in Reith v. County of Mountrial, 104 N.W. 2d 667, 670-671 (N.Dak. Sup. Ct. 1960) and in State v. Crocker's Estate, 38 Ala. App. 306, 83 So. 2d 261 (Ct. App. 1955). See generally Griffin Memorial Hosp., supra.

${ }^{133}$ See 41 Am Jur 2d, Incompetent Persons, 858 at 597; on pertinent trust issues generally, see Third Nutional Bank in Nashville v. Brown, 691 S.W. 2d 557 (Tenn. Ct. App. 1985).

At least one court has suggested that the decision to invade a trust should be based upon the chances for the patient's recovery and ultimate release. See Commonwealth v. Sharrett, 218 Va. 684, 240 S.E. 2 d 522 (1978).

${ }^{134}$ Clarendon Holding Co. v. Witherspoon, 201 S.E. 2d 924 (S.C. Sup. Ct. 1974).

${ }^{135} \mathrm{Id}$, at 927.

:36The distinction between IST and NGRI has been blurred in at least one case, where a defendant was committed following a plea of "not guilty by reason of insanity" until such time as he "is no longer insane." Hawley, 28 Cal. Rptr. at 719-720. While no finding was ever made with respect to this plea, the court 


\section{(I) ISTS}

Courts construing claims made by patients hospitalized pursuant to a finding of incompetency to stand trial ${ }^{137}$ have generally found that such patients may be billed for their care and maintenance while so institutionalized, as such a patient is neither "under the direct control of the criminal authorities"138 nor a convict, ${ }^{139}$ nor is the commitment seen as being punitive in nature. ${ }^{140}$ Elsewhere, even though a patient was under the continuing control of a court with criminal jurisdiction as well, the fact that her commitment followed a finding of mental illness made it appropriate to subject her to the same sort of financial liability as a "civil" patient. ${ }^{141}$

\section{(2) NGRIs}

Courts are split, however, on the question of whether such charges can be assessed against patients committed following a finding of not guilty by reason of insanity. ${ }^{142}$ Although not all of these decisions reflect the most precise and detailed analysis, the disposition of these cases seem to reflect generally whether the court views the rationale of the commitment as treatment for benefit of the patient or protection for the benefit of society. ${ }^{143}$

\section{(a) Upholding statutes assessing charges}

In Matter of Guardianship of Nelson, ${ }^{144}$ the guardian of the estate ${ }^{145}$ of a patient who had been committed to a state psychiatric hospital following an insanity acquittal appealed from a trial court order mandating payment of the patient's "care and maintenance" while hospitalized, ${ }^{146}$ on the grounds that the

construed it as an admission of the underlying charge (of which there appeared to be no factual doubt) which,

"but for M'Naughton type insanity, would affect the crime charged." Id. at 720.

${ }^{137}$ See generally Jackson v. Indiana, 406 U.S. 715 (1972).

${ }^{138}$ Commonwealth Department of Mental Health \& Mental Retardation v. Jenkins, 297 S.E. 2d 692, 695

(Va. Sup. Ct. 1982).

${ }^{139}$ State v. Kosiorek, 5 Conn. Cir. 542, 259 A. 2d 151, 152 (App. Div. 1969).

${ }^{140} I d$.

${ }^{141}$ State ex rel. Mental Health Commissioner v. Guardianship of Wiseman, 393 N.E. 2d 235, 237 (Ind. Ct. App. 1979). See also, In re Estate of Schneider, 50 Ill. 2d 152, 154, 277 N.E. $2 d 870$ (Sup. Ct. 1971) (trial competency proceeding "for the protection of [the patient's] constitutional rights to due process and for his benefit-not for the protection of the public").

${ }^{142}$ The constitutionality of commitment procedures following an NGRI finding has been the topic of significant caselaw development and strenuous debate over the past decade. See, e.g., Jones v. United States, 463 U.S. 354 (1983); State v. Krol, 68 N.J. 236, 344 A. 2d 289 (Sup. Ct. 1975).

${ }^{143}$ But see Note, 85 W. VA. L. REV., supra note 52, at 124 (distinctions between involuntarily committed civil patients and patients committed via the criminal process "unsound if both groups are deprived of their liberty under state mandated procedures").

14498 Wis. 2d 261, 296 N.W. 2d 736 (Sup. Ct. 1980).

${ }^{145}$ See generally Part III(C), infra.

${ }^{146}$ Under the then-operative statutory scheme, a person "receiving care, maintenance, services and supplies provided by any institution in this state . . . shall be liable for the cost of the care, maintenance, services, and supplies . . " Wis. Stat. Ann. $\$ 46.10$ (2) (1979). The one exception to this statute exempted persons over the age of 18 in "prisons." Wis. Stat. Ann. $\$ 46.10(2 \mathrm{~m})$ (1979). See Nelson, 296 N.W. 2d at 737-738. 
statutorily-mandated disparate treatment ${ }^{147}$ of insanity acquittees and prisoners was arbitrary and capricious. ${ }^{148}$

The Wisconsin Supreme Court rejected his argument that the statutory scheme violated the equal protection clauses of either the state or federal constitutions, reasoning that (1) such a statute need only satisfy the rational basis test (since fundamental rights were not implicated), ${ }^{149}$ and (2) the "supplies, services and care"150 received by prisoners differed from those received by mental patients. ${ }^{1 s t}$

The statutory exemption for prisoners was "justifiable as a legislative distribution of the economic burdens of institutional care," the court reasoned, noting that there was both a "theoretical and factual difference" in the services received by prisoners and other institutionalized persons:

\begin{abstract}
Theoretically the prisoner is incarcerated as a measure to prevent harm to the public. Restrained of his liberty, he is not free to commit criminal acts. This is an historic and a primary reason for the existence of prisons. Factually, the services rendered to the prisoner are not geared to return him to a state of mental or physical health. They are geared to sustain him on a day-to-day basis while he serves out his term .... ${ }^{152}$
\end{abstract}

On the other hand, persons receiving care and services in a non-penal institution "share a common trait [: the receipt of] care and services which inure primarily to their benefit as opposed to the benefit of the public."153 While the confinement of some of this group of persons "will be of some value to society $[, t]$ his benefit ... may reasonably be viewed as secondary to an overriding purpose of treatment to benefit the individual."154 Such a difference provides "a reasoned ground for the exemption given the prisoners,"15s and the constitutionality of the statute was thus upheld. ${ }^{156}$

In a companion case, the state Supreme Court also found that the statutory scheme - which vested in the state Department of Health and Human Services the power to determine from whom payment will be sought and in what

\footnotetext{
${ }^{147}$ See supra note 146.

${ }^{148}$ Nelson, 296 N.W. $2 d$ at 740.

${ }^{149} I d$. at 739 , relying on Ortwein v. Schwab, 410 U.S. 656,660 (1973) (statute operates in areas of economics, social welfare).

${ }^{150}$ See supra note 146.

${ }^{151}$ Nelson, 296 N.W. $2 d$ at $740-741$.

${ }^{152} \mathrm{Id}$. at 740.

${ }^{153}$ Id.

154Id. But cf., Jones, 463 U.S. at 364, quoting Lynch v. Overholser, 369 U.S. 705, 714 (1962) ("The fact that the accused was found to have committed a criminal act [as established in Jones by the verdict of not guilty by reason of insanity] is 'strong evidence that his continued liberty could imperil "the preservation of the peace" '").

${ }^{155}$ Nelson, 296 N.W. 2d at 740. This distinction has been relied upon elsewhere. See State ex rel. Dorothea Dix Hospital v. Davis, 27 N.C. App. 479, 219 S.E. 2 d 660 (Ct. App. 1975) (Davis).

156Id. at 740-741. The court noted that "[v]irtually every reported decision" came to a similar conclusion on the equal protection question. Id. at 741 n.5, and see cases cited. But see Part III(D)(2)(b), infra.
} 
amount - did not constitute an unlawful delegation of legislative power. ${ }^{157}$ As it was established state law that such a delegation will be upheld "if the purpose of the delegating statute is ascertainable and there are procedural safeguards to insure that the board or agency acts within that legislative purpose," 158 it was "clear beyond doubt" that the statute in question - reflecting "clear and well defined" policies and purposes 159 - should be upheld.

Elsewhere, in another case with a similar fact-setting, ${ }^{160}$ a court has rejected the argument that the assessment of such charges amounted to a tax in violation of state and federal constitutional provisions requiring uniformity and reasonableness in the mode of tax assessments. ${ }^{161}$ As the statutory cost of "care, treatment and maintenance"162 was placed on all patients, it did not impose a non-uniform tax; ; ${ }^{163}$ also, the statutory cost was "not characteristic of a tax at all," but rather represented "compensation for services rendered." 164

\section{(b) Upholding challenges to statutes}

On the other hand, the state courts of Connecticut have struck down statutes imposing liability on persons found NGRI on the theory that there was no reasonable ground to differentiate between insanity acquittees and "ordinary prisoners." 165 There, where the statutory scheme specifically made no distinction between NGRI patients and those civilly committed, ${ }^{166}$ the court found several critical differences between the two categories which proved fatal to the classification for the purposes of a rational basis inquiry. ${ }^{167}$

First, under the state laws which controlled at the critical time periods, ${ }^{168}$ the touchstone of a civil commitment was mental illness and fitness for treatment; an insanity acquittee, however, could not be released from confinement absent a finding as to his dangerousness to self or others. ${ }^{169}$ While a court could not

${ }^{157}$ Matter of Guardianship of Klisurich, 98 Wis. 2d 274, 296 N.W. 2d 742, 744-746 (Sup. Ct. 1980). See also, e.g., Davis, 219 S.E. $2 d$ at 663.

158Id. at 745, citing, inter alia, State (Dept. of Admin.) v. ILHR Dept., 77 Wis. 2d 126, 134, 252 N.W. 2d 353 (Sup. Ct. 1977).

${ }^{159} \mathrm{Id}$. at 745,746 .

${ }^{160}$ In Davis, the defendant had been committed to a state hospital following an insanity acquittal. 219 S.E.

$2 \mathrm{~d}$ at 662 .

${ }^{161} \mathrm{Id}$. at 663 .

${ }^{162}$ N.Car, Gen. Stat. $\$ 143-117$ (1983) provided that all patients admitted to Dorothea Dix Hospital "are hereby required to pay the actual cost of their care, treatment, training, and maintenance."

${ }^{163} \mathrm{Id}$, at 663 .

${ }^{164} \mathrm{Id}$. The court also rejected the defendant's argument that payment was "a taking of private property without just compensation" as he actually received the services for which payment was sought. Id. at 664 .

${ }^{165}$ State v. Reed, 192 Conn. 520, 473 A. 2d 775, 780 (Sup. Ct. 1984); State v. Miller, 192 Conn. 532, 472 A. 2d 1272 (Sup. Ct. 1984). For earlier developments in Connecticut, see McAuliffe, supra.

${ }^{166}$ Conn. Gen. Stats. $\$ 17-317$ (1975) provided that "the expense for the support and treatment of [a] person [found NGRI who has been committed for confinement or treatment] shall be computed and paid for in the same manner as is provided . . . for patients committed by courts of probate." See Reed, 473 A. $2 d$ at 776 n.2.

${ }^{167} \mathrm{Id}$. at $778-781$.

${ }^{168}$ See Conn. Gen. Stats. $\$ 17-178$ (1975), since substantially rewritten, see Conn. Gen. Stats. $\$ 17-178$ (1985). Cf. O'Connor v. Donaldson, 422 U.S. 563 (1975); see generally Fasulo v. Arafeh, 173 Conn. 473, 378 
interfere with a hospital decision to release a civilly-committed patient, an insanity acquittee could only be released with court approval, "Unlike one whose mental illness has never been manifested by performing a criminal act, ... the focus of the inquiry with respect to the acquittee is upon the protection of the community, the same consideration which is of primary concern in relation to the imprisonment of persons convicted of crimes." ${ }^{\prime 170}$

Although the court conceded that there were some differences between NGRI patients and prisoners as to stigma, as to allocation of jurisdiction as between executive agencies, and as to release mechanisms, these "have no particular relevance to the propriety of requiring an insanity acquittee to pay for the same services which are provided to an ordinary prisoner without charge, because they are not related to comparative financial ability or need for treatment."171

Finally, the court distinguished cases from other jurisdictions which had rejected equal protection challenges ${ }^{12}$ since it did not appear "that the statutory criteria for commitment or release of persons confined by order of the criminal court differed from those applicable to civil commitments."173

Elsewhere, a state statute providing that the costs of hospitalization of an NGRI patient were taxable against the state rather than the patient was upheld in light of a constitutional attack by the Director of the State Department of Public Health and Welfare, ${ }^{174}$ the court rejecting the plaintiff's argument that the statute violated a state constitutional provision which barred "grants or gifts" by the authorization of "free hospital treatment to individuals of means." 175

The fact that the NGRI patient was automatically committed ${ }^{176}$ to the state hospital (because of the state's "interest and obligation . . . to protect the public against dangerous individuals") ${ }^{177}$ - with the attendant permitted "by-pass of a person's usual right to a [due process] hearing"178 - made it "[clear that] this is not a case where the State is making a simple gift of medical services."179

\section{(C) Following arrest or apprehension}

Finally, New Jersey's state courts have ruled that cost of care and maintenance must be paid in two other circumstances involving the criminal process. In the first, a trial court ruled that persons transferred from county jails to state hospitals following arrest and detention on criminal charges were so obligated,

${ }^{170} I d$. at 780 (emphasis added).

${ }^{171} I d$.

${ }^{172 I n c l u d i n g, ~ i n t e r ~ a l i a, ~ D a v i s, ~ s u p r a . ~ S e e ~ R e e d, ~} 473$ A. 2d at 781.

${ }^{173} I d$.

${ }^{174}$ Robb v. Estate of Brown, 518 S.W. 2 d 729 (Mo. Ct. App. 1974). The statute before the court in Robb was subsequently amended so as to make the patient or his estate responsible for costs of hospitalization in cases following "acquittal because of lack of responsibility due to mental disease or defect," see Rev. Stat. Mo. $\$ 552.080 .3$ (2) (1980), upheld in State ex rel. Foltz v. Ahr, 666 S.W. 2d 777, 779-781 (Ct. App. 1983).

${ }^{175} R o b b, 518$ S.W. 2d at 735, paraphrasing Mo. Const'n, \$38(a), Art. III.

${ }^{176}$ See Jones, 463 U.S. at 361-372.

${ }^{177}$ Robb, 518 S.W. $2 d$ at 735.

178Id. at 736. See generally Addington v. Texas, 441 U.S. 418 (1975), and Vitek v. Jones, 445 U.S. 480 (1980).

${ }^{179} I d$. 
reasoning that a contrary ruling might enable individuals to escape financial liability for hospitalization by electing to not post bail (and thus be eligible for jail-hospital transfers). ${ }^{180}$

In the second, and most unusual case, liability for care and maintenance was upheld by the state Supreme Court in the case of an individual who, after having previously been civilly committed and institutionalized in a civil hospital, was transferred to a maximum security facility for the "criminally insane" after he allegedly assaulted and killed two other patients in the civil hospital, notwithstanding the fact that no criminal prosecution for homicide was contemplated. ${ }^{181}$

\section{Representative Payee Status}

Both federal ${ }^{182}$ and state ${ }^{183}$ statutes provide for the appointment of representative payees to manage the monetary benefits of beneficiaries determined incapable of managing certain of their own assets. ${ }^{184} \mathrm{~A}$ pre-existing finding of the beneficiary's legal incompetency is not always essential under the language of the federal provisions if it "appears . . . that the interest of an applicant entitled to a payment [of social security benefits] would be served thereby."18s

In upholding the constitutionality of the federal scheme, the Tenth Circuit construed the Supreme Court's decision in Mathews v. Eldridge ${ }^{186}$ to hold that the due process clause does not require prior notice and an opportunity to contest when an institutionalized Social Security beneficiary is alleged to be incompetent and incapable of managing his own affairs. ${ }^{187}$

After ruling that exhaustion of administrative remedies was not required, the court applied the three-part balancing test of Eldridge, ${ }^{188}$ and determined that

\footnotetext{
${ }^{180}$ In re Truslowe, 42 N.J. Super. 23, 125 A. 2 d 741, 745 (J. \& D.R. Ct. 1956).

${ }^{181}$ State y. LeVien, 44 N.J. 323, 209 A. 2d 97, 99 (Sup. Ct. 1965) (quoting letter from county prosecutor to State Attorney General).

${ }^{182}$ See 42 U.S.C. $\$ 405(\mathrm{j})$ (1985 Supp.); see 20 C.F.R. $\$ 404.2001$ to .2065 (1985).

${ }^{183}$ See, e.g., Ky. Rev. Stats. $\$ \$ 210.290$ (1982), 387.620 (1984), construed in Commonwealth v. Cabinet for Human Resources, 686 S.W. 2d 465 (Ky. Ct. App. 1984), and Rev. Co. Wash. 72.33 .670 (1982), construed in Duffy v. State, Dep't of Social and Health Services, 90 Wash 2d 673, 585 P. 2d 470 (Sup. Ct. 1978).

${ }^{184}$ See, e.g., McGrath v. Weinberger, 541 F. 2d 249, 251 (10 Cir. 1976), cert. den. 430 U.S. 933 (1977). See generally MCCORMICK, SOCIAL SECURITY CLAIMS AND PROCEDURES (3d ed. 1983), §15 at 2021; 3 SOCIAL SECURITY PRACTICE GUIDE (Matthew Bender 1985), \$\$22.01 to 22.07 at 22-1 at 22-13 (Practice Guide); BLOCH, FEDERAL DISABILITY LAW AND PRACTICE. (1984), \$4.14, at 252-255.

The "representative payee" scheme is described in detail in Jordan v. Heckler, 744 F. 2d 1397 (10 Cir. 1984), suppl. proceeding 808 F. 2 d 733 (10 Cir. 1987) (mandating periodic accounting by payees).

18542 U.S.C. $\$ 405$ (j) (1985 Supp.); see generally, 20 C.F.R. $\$ 404.2001$ (1985), and especially, 20 C.F.R. $\$ 404.2001$ (b) (2) (1985) ("We may appoint a representative payee even if the beneficiary is a legally competent individual"). See also 20 C.F.R. $\$ 404.2065$ (1985) (providing accounting procedures to be followed by representative payee, and establishing mechanism for submission of periodic written reports).

186424 U.S. 319 (1976).

${ }^{187}$ McGrath, 541 F. 2 d at 253-254.

${ }^{188} \mathrm{Id}$. at 252-253.
}

[F]irst, the private interest that will be affected by the official action; second, the risk of an erroneous deprivation of such interest through the procedures used, and the probable value, if any, of substitute procedural safeguards; and finally, the government's interest, including the 
no such prior hearing was required. First, it distinguished the facts of Eldridge, which involved the termination of benefits, from the case in question, which dealt with "a deprivation of free use of benefits." Since there was no due process violation in Eldridge (which allowed termination without a prior hearing), "it would be an unwarranted departure on our part" to order such a hearing in a case involving "no termination of benefits."

Second, it characterized the risk of erroneous deprivation of the beneficiary's interest in the free use of his benefits as "relatively slight" or "minimal," adding that it would be "unwarranted conjecture" to speculate that the evaluations of incompetency made by hospital staff and Social Security psychologists reflected "anything other than a sincere determination" that the appointment of a representative payee would serve the "best interests" of the beneficiary. Third, it concluded that the governmental interest was "substantial," both as to time and expense and as to administrative expedience. ${ }^{190}$

Substantively, other representative payee cases have considered: (1) the role of the payee in applying a patient's assets to institutional care, (2) the need for actual notice prior to a determination of financial responsibility ${ }^{191}$ to a patient with a payee but without a legal guardian, and (3) the appropriateness of the appointment of the state agency with supervisory powers over the patient as the payee.

While it is clear that money paid to a representative payee belongs to the beneficiary, ${ }^{192}$ and that the payee is accountable for payments made to him on account of his beneficiary, ${ }^{193}$ there is some authority ${ }^{194}$ to suggest that the payee may be compelled to apply social security benefits to provide for the patient's care and maintenance while institutionalized. ${ }^{195}$

function involved and the fiscal or administrative burden that the additional or substitute procedural requirements would entail.

424 U.S. at 335.

${ }^{189} \mathrm{McGrath}, 541 \mathrm{~F} .2 \mathrm{~d}$ at 253.

190Id. at 253-254:

We agree with the government's contention that requiring a prior hearing would place it in "the anomalous position of either paying benefits to a person who is incapable of managing these benefits or, on the other hand, holding up all benefit payments until a capability hearing is rendered."

(citation omitted).

On the other hand, the Social Security Administration will "generally" notify beneficiaries of its decisions and will given them some sort of opportunity to object to proposed action. See Bloch, supra note 184, at 253 , and see 20 C.F.R. $\$ 404.2030$ (a) (1985).

i1See Part III(A), supra.

192State v. Kosiorek, 5 Conn. Cir. 542, 259 A. 2d 151, 154 (App. Div. 1969), citing 42 U.S.C. $\$ 405($ j).

${ }^{193}$ Id. at 154-155, citing 20 C.F.R. $\$ 404.1609$ (predecessor to 20 C.F.R. $\$ 404.2041$ (1985)).

${ }^{199}$ But see Part V, infra.

${ }^{199}$ Kosiorek, 259 A. 2 d at 155, citing 20 C.F.R. $\$ 404.1606$ (predecessor to 20 C.F.R. $\$ 404.2035$ (1985)): ("It is considered in the best interests of the beneficiary for the . . . person to whom payments are certified on the beneficiary's behalf to allocate expenditure of the payments so certified in a manner which will facilitate the beneficiary's earliest possible rehabilitation or release from the institution or which otherwise will help him live as normal a life as practicable in the institutional environment"). But see, Woodall v. Bartolino, Civil No. 85-1781(MTB) (D.N.J., Oct. 24, 1985). 
On the other hand, provision of notice of a financial responsibility determination hearing solely to a payee violates due process in cases where "the patient is not subject to any legally declared disability." not "the equivalent of a legal guardian"; second, even though the patient's property is "in the hands of the representative payee, [it] is still [the patient's] property" and "no determination regarding that property can be made without notice to him or a legally appointed guardian."197

Finally, an intermediate state appeals court ${ }^{198}$ has construed state statutes ${ }^{199}$ establishing priorities in the appointment of payees to allow for the designation of a state human services department "as a matter of last resort,"200 and thus reinstated a trial court determination so appointing the Cabinet for Human Resources as payee where it found that there was "no other available and willing individual or entity to assume such [a role]."201

\section{Attachment of Government Benefits to Pay for "Care and Maintenance"}

A significant issue which has not been extensively litigated ${ }^{202}$ is the question of whether a patient's Social Security benefits may be attached by a state or county government to pay for the care and maintenance of an institutionalized mentally disabled person, in light of a federal statutory provision which appears to totally bar such attachments. ${ }^{203}$

Under 42 U.S.C. \$407(a) (1983) ("\$407"):

The right of any person to any future payment ... shall not be transferrable or assignable, at law or in equity, and none of the moneys paid or payable or rights existing under this subchapter shall be subject to execution, levy, attachment, or other legal process . . . ${ }^{204}$

\footnotetext{
${ }^{196}$ Duffy, 585 P. $2 d$ at 474.

${ }^{197}$ Id. Cf. McCormick, supra note 184, at 20-21 (where a beneficiary was found NGRI and subsequently committed to a state hospital [which was appointed representative payee on his behalf], such an NGRI finding was not an adjudication of insanity for all purposes, and the Social Security Administration would undertake to determine whether the beneficiary was capable of managing his own benefits and whether direct payments should be made directly to him, citing Soc. Sec. Ruling 73-29).

${ }^{198}$ Commonwealth v. Cabinet for Human Resources, 686 S.W. 2d 465 (Ky. Ct. App. 1984).

${ }^{199}$ See, e.g., Ky. Rev. Stat. $387.600(1)$ (1984).

${ }^{200}$ Cabinet For Human Resources, 686 S.W. $2 d$ at 468.

${ }^{201} \mathrm{Id}$. See also, e.g., Estate of Peter C., 488 A. 2d 468, 470 (Me. Sup. Jud. Ct. 1985) (statute barring institution housing incapacitated persons from serving as guardian does not automatically bar its employees from being so named).

But see Practice Guide, supra note 184, \$22.03[2], at 22-4 (while appointment of the director of a state institution as representative payee for an institutionalized recipient is not improper per se, such appointment often creates an inherent conflict of interest, because of the institution's usual dual role of "creditor [and] caretaker," citing Tidwell v. Weinberger, [Fed. Transfer Binder Jan. 1976-Jan, 1977] Unempl. Ins. Rep. (CCH) 114,756 (N.D. III., June 23, 1976).

${ }^{202}$ But see, Woodall v. Bartolino, Civil No. 85-1781 (MTB) (D.N.J., Oct. 24, 1985), discussed infra at text accompanying notes $216-231$.

${ }^{203}$ See 42 U.S.C. $\$ 407$ (1983).

${ }^{204} \mathrm{~A}$ new section of this statute is explicit:
}

No other provision of law, enacted before, on or after the date of the enactment of this section, may be construed to limit, supercede, or otherwise modify the provisions of this section except to the extent that it does so by express reference to this section. 
In the lead case of Philpott v. Essex County Welfare Board, ${ }^{205}$ the Supreme Court rejected a county's efforts to obtain bank account funds ${ }^{206}$ consisting of Social Security disability benefits so as to partially offset county welfare payments. 207 "We see no reason," ruled the court, "why a state, performing its statutory duty to take care of the needy, should be in a preferred position as compared with any other creditor." It construed $\$ 407$ as imposing "a broad bar against the use of any legal process to reach all social security benefits." 208

There has been some dispute in the Circuits as to the application of $\$ 407$ to care and maintenance situations. ${ }^{209}$ The Fifth Circuit distinguished Philpott in a case involving a chronic institutionalized and adjudicated incompetent patient who possessed over $\$ 40,000$ in social security and veterans' benefits. ${ }^{210}$ Because the state was meeting all of the recipient's needs (and would have to do so for the remainder of the patient's life), the patient's guardian would never have the opportunity to use the benefits for her ward's care; thus, allowing attachment would not circumvent the purpose of the benefits program, which was to provide for the care and maintenance of the recipient. ${ }^{211}$

On the other hand, the Seventh Circuit has upheld $\$ 407$ 's broad exclusion in a case striking down the use of a standard consent form through which a state hospital asked patients to authorize the facility to reimburse itself for hospitalization costs from the patient's Social Security benefits. ${ }^{212}$

In that case, the form failed to clearly inform individual patients that their reimbursement decision was, in reality, a voluntary one, that the hospital would provide them with treatment even if they refused to sign, and that their benefits were not otherwise subject to the legal process. ${ }^{213}$

This conflict was, in great measure, resolved in 1983 when the Social Security Act was amended to include $\$ 407$ (b), which stated explicitly that $\$ 407$ (a) could

42 U.S.C. $\$ 407$ (b) (1983) ("\$407(b)").

SSI benefits are also covered by these provisions. 42 U.S.C. $\$ 1383$ (d) (1) (1985 Supp.). See also, 20 C.F.R. $\$ 404.1820$ (1985).

205409 U.S. 413 (1973).

${ }^{206}$ Cf., e.g., Porter v. Aetna Casualty Co. 370 U.S. 159, 162 (1962) (veterans' benefits deposited in savings and loan association on veteran's behalf retained the "qualities of moneys" and was not a non-exempt permanent investment, quoting Trotter v. Tennessee, 290 U.S. 354 (1933)). See infra note 210.

207 Philpott, 409 U.S. at 415-417.

$208 I d$. at $416,417$.

${ }^{209}$ See generally Part III(A), supra.

${ }^{210}$ Dep't of Health \& Rehabilitative Services v. Davis, 616 F. 2d 828, 829 (5 Cir. 1980) (Davis II). The patient had been institutionalized in public facilities for nearly thirty years. Id. at 830 .

${ }^{21}$ Id. at 215-216. Davis II thus distinguished Philpott, where the non-institutionalized welfare recipient was at least partially responsible for his own care. See 409 U.S. at 415-417.

${ }^{212}$ Tidwell v. Schweiker, 677 F. 2d 560, 566-568 (7 Cir. 1982).

${ }^{213}$ Id. at 563-564.

In other fact settings, federal courts have interpreted $\$ 407$ strictly to protect bank accounts from garnishment where Social Security funds may have been intermingled with other moneys, see, e.g., Fiberg $v$. Sullivan, 634 F. 2d 50 (3 Cir. 1980); see also Reigh v. Schleigh, 595 F. Supp. 1535, 1555 n.15 (D. Md. 1984); Dionne v. Bouley, 583 F. Supp. 307, 319 (D.R.I. 1984), aff' 757 F. 2 d 1344 (1 Cir. 1985); Deary v. Guardian Loan Co., Inc., 534 F. Supp. 1178, 1187-1188 (S.D.N.Y. 1982), and to protect such benefits from recoupment following past overpayments, see McKenzie v. Heckler, 605 F. Supp. 1217, 1219 (D. Minn. 1985); see also Page v. Heckler, 596 F. Supp. 1543 (M.D. Pa. 1984); McDaniels v. Heckler, 571 F. Supp. 80 (D. Md. 1983); Ellender v. Schweiker, 575 F. Supp. 590 (S.D.N.Y. 1983). 
be modified only by express reference. ${ }^{214}$ The legislative history to this amended section is unambiguous:

Since 1935 the Social Security Act has prohibited the transfer or assignment of any future social security or SSI benefits payable and further states that no money payable or rights existing under the Act shall be subject to execution, levy, attachment, garnishment or other legal process, or to the operation of any bankruptcy or insolvency law.

Based on the legislative history of the Bankruptcy Reform Act of 1978 , some bankruptcy courts have considered social security and SSI benefits listed by the debtor to be income for purposes of a Chapter XIII bankruptcy and have ordered [the Social Security Administration] in several hundred cases to send all or part of a debtor's benefit check to the trustee in bankruptcy.

Your Committee's bill specifically provides that social security and SSI benefits may not be assigned notwithstanding any other provisions of law, including P.L. 95-598, the Bankruptcy Reform Act of $1978 .{ }^{219}$

This backdrop has been recently carefully examined in Woodall $v$. Bartolino, ${ }^{215}$ where plaintiffs sought, inter alia, ${ }^{217}$ a declaration that the benefits in question were exempt from attachment by county officials to pay for their care and maintenance at a state psychiatric hospital. ${ }^{218}$ In finding that the benefits were so exempt, ${ }^{219}$ the district court specifically found that, if Davis II (the Fifth Circuit case which had allowed for attachment) ${ }^{220}$ "has continuing life, . . . it [must be] limited to the extreme factual situation presented . . . in that case."221

\footnotetext{
${ }^{214}$ See supra note 204.

${ }^{21 s}$ H.R. Rep, No. 98-25, 98th Cong., 1st Sess. 82-83 (1983); see also House Conf. Rep., No. 98-47, 98th Cong., 1st Sess. 153 (1983).

This amendment has been construed to explicitly supercede cases where bankruptcy courts had ordered the use of Social Security benefits to pay creditors, see Matter of Treadwell, 699 F. 2d 1050, 1053 (11 Cir. 1983); United States v. Decall, 704 F. 2d 1513, 1516 (11 Cir. 1983).

${ }^{216}$ Civil No. 85-1781 (MTB) (D.N.J., Oct. 24, 1985).

${ }^{217}$ See id. at 22-24.

${ }^{218}$ Woodall, slip op. at 2. The Woodall class consisted of "1) all Mercer County residents receiving Social Security benefits who have been or in the future will be hospitalized in a New Jersey state psychiatric institution and who have been or in the future will be ordered to pay for their hospitalizations from their Social Security benefits, and 2) all persons who now act or in the future will act as representative payees for such Mercer County residents." Id.
}

${ }^{219} \mathrm{Id}$. at 12-22.

${ }^{220}$ See supra text accompanying notes 215.

221 Woodall, slip op. at 17:

The individual in Davis [II] had been in state institutions for almost thirty years, had long been judged incompetent, had little hope of ever emerging from the institution in which he resided, and his guardian had accumulated a large amount of funds which, because of this individual's situation, would almost certainly never be used for his care and maintenance, unless they were turned over to the state which was providing for his care and maintenance and had been for years. Here, of course, plaintiff Alfreda K. has been intermittently institutionalized and otherwise resides with plaintiff Woodall.

Id. 
Although the court found it appropriate that a portion of plaintiffs' social security benefits be utilized to pay for patients' care and maintenance costs, it specified that it was the responsibility of the federal government (not the state) to enforce a representative payee's duties, and that this enforcement was limited to liability for the misuse of funds and the appointment of a new payee. ${ }^{222}$ On the other hand, institutional care payments "for the beneficiary's current maintenance"223 are appropriate ${ }^{224}$ and may include - in cases where the recipient is institutionalized for "mental or physical incapacity"22s - "the customary charges in the institution."226

Thus, the court concluded that, while defendants may not use the power of state courts to enforce the application of Social Security benefits for the care and maintenance of an institutionalized individual, it would nonetheless be "appropriate" for these benefits to be applied to a patient's care and maintenance. ${ }^{227}$

Procedurally, the court found it appropriate for defendant Bartolino ${ }^{228}$ to convene a "non-adversarial" hearing, in conformity with state statute, to inquire into the willingness and ability of a representative payee to pay a sum out of social security benefits towards the cost of a patient's care and maintenance: ${ }^{229}$

While the representative payee has discretion in this regard, and while it may be quite clear that, for a variety of reasons, nothing or something can or should be contributed, the exercise of that discretion can be reviewed and enforced by the District Office [of the Social Security Administration] and not by defendant Bartolino or by the state courts. ${ }^{230}$

The court thus entered a preliminary injunction, prohibiting defendants from enforcing judicial orders for care and maintenance against the plaintiffs' Social Security benefits. ${ }^{231}$

222Id. at 18, citing 20 C.F.R. $\$ 404.2041$ (1985); 404.2050 (1985).

${ }^{223} 20$ C.F.R. $\$ 404.2040$ (a) (1985).

${ }^{224}$ Woodall, slip op. at 18.

${ }^{225} 20$ C.F.R. $\$ 404.2040$ (b) (1985).

${ }^{226} I d$.

227 Woodall, slip op. at 21:

Thus, while such payments must be voluntary, it is nonetheless clear that a representative payee has a responsibility, if it is possible to do so, to make such payments, a responsibility and exercise of discretion the violation of which can be enforced by removing the representative payee and, perhaps, naming as payee the institution caring for the payment. See 220 C.F.R. $\$ \$ 404.2041,404.2050,416.601(a)(2)$.

Id. Cf. Cabinet for Human Resources, supra.

228 Named defendant Bartlolino was the county adjuster, the official responsible for investigating the financial ability of patients and their relatives to pay for the costs of institutionalization, and for serving as the "referee" for the purpose of taking testimony on that question. Woodall, slip op. at 8; see N.J.S.A. 30:434 (1981); see generally, N.J.S.A. 44:1-1 (1940), and N.J.S.A. 44:7-1 (1980 Supp.).

229 Woodall, slip op. at 21.

230 Id. at 21-22.

231Id. at 22-23. 


\section{Conclusion}

The above discussion reveals, at best, a "mixed bag" of caselaw. While several opinions reflect serious decision-making on the part of the courts, ${ }^{232}$ most involve simply workman-like constructions of older statutory schemes, with little consideration paid to the parallel constitutional and statutory developments in other areas of patients' rights law. ${ }^{233}$ Rarely are the collateral economic issues - those related to ex-patient self-sufficiency in the community and the relationship between lack of deinstitutionalization planning to post-hospitalization homelessness - considered, and, only in a few cases-notably Vecchione, Chill, and the unreported Woodall decision-is there a sense that the courts were looking at the economic issues as part of the larger fabric of the constitutional and civil rights of the institutionalized. ${ }^{234}$

It is somewhat difficult to attempt to discern doctrinal threads or trends in this group of cases. That difficulty is probably a reflection of the reality that the cases were decided episodically and idiosyncratically, and not with any strong sense (on the part of the courts) that the entire body of patients' rights law is one which is in significant flux. ${ }^{235}$ To some extent, this is probably a reflection of the fact that few of the cases appear to be the result of conscious, affirmative law reform litigation. ${ }^{236}$ This may help account for the fact that-even in those areas in which constitutional principles have been shaped - there has been surprisingly little "follow-up" litigation in other jurisdictions following the initial decision. ${ }^{237}$

It is also unclear as to what paths further litigation in this area will take. Any prediction here is dependent on several paradoxical variables: a legislative countertrend which is resulting in the re-loosening of civil commitment criteria in many states (as a reflection that the "pendulum" has "swung too far" toward the

${ }^{232}$ E.g., Vecchione v. Wohlgemuth, supra, discussed in Part II(A), supra; Chill v. Mississippi Reimbursement Commission, supra, discussed in Part $\mathrm{III}(\mathrm{C})$, supra; Woodall v. Bartolino, supra, discussed in Part V, supra.

${ }^{233}$ See, e.g., sources cited supra note 4.

${ }^{234} \mathrm{E}$. g., in Vecchione, the court looked carefully at the implications of the presumption of incompetency; in Chill, the court took note of the substantive and procedural due process decisions which have significantly altered the relationship between patients and hospitals; in Woodall, the court showed sensitivity to the special problems of the "intermittently institutionalized" patient.

${ }^{235}$ See generally Last Frontier, supra note 4. For an example, see the sharp contrast in the way the Courts of Appeals have considered whether or not there is a right to community treatment following the Supreme Court's decisions in Youngberg v. Romeo, 457 U.S. 307 (1982), and Pennhurst State School \& Hospital v. Halderman, 104 S. Ct. 900 (1984). Compare, e.g.s Thomas S. v. Morrow, 781 F. 2 d 367 (4 Cir. 1986), cert. den. 106 S. Ct. 1992 (1986), and Clark v. Cohen, 794 F. 2 d 79 (3 Cir. 1986), cert. den. 55 U.S.L.W. 3358 (1986) (applying the right), to Society for Good Will to Retarded Children v. Cuomo, 737 F. 2d 1239 (2 Cir. 1984) and Phillips v. Thompson, 715 F. 2d 365 ( 7 Cir. 1983) (refusing to apply the right).

${ }^{236}$ Vecchione is a clear exception. For a comprehensive analysis of a prototypical law reform case involving the right of institutionalized patients' to treatment, see, e.g., Jones \& Parlour, eds., WYATT V. STICKNEY: RETROSPECT AND PROSPECT (1981). But see, Stevens, "Wyatt v. Stickney Concludes With A Whimper," 11 MENT. \& PHYS. DIS. L. RPTR. 139 (1987). On the question of law reform and public law litigation in general, see, e.g., Chayes, The Role of the Judge on Public Law Litigation, 89 HARV. L. REV. 1281 (1976); Johnson, The Role of the Federal Courts in Institutional Litigation, 32 ALABAMA L. REV. 271 (1981).

${ }^{257}$ See, e.g., supra notes $25,44$. 
"civil liberties-model" in cases such as Lessard v. Schmidt), ${ }^{238}$ at the same time that federal legislation is making available (for the first time) funds to each state to develop "Protection and Advocacy Systems" to provide representation to the institutionalized mentally disabled; ${ }^{239}$ the increased hostility on the part of many federal courts toward the idea of mental disability law reform ${ }^{240}$ at a time when litigants are beginning to approach state courts as a preferred forum for civil rights litigation on behalf of the population in question; ${ }^{241}$ the realization that, no matter what treatment and social advances are made in coping with the problems raised by deinstitutionalization, ${ }^{242}$ economic issues must be given equal consideration in any attempts to grapple with problems of the homeless. ${ }^{243}$

While these issues are still being sorted out, it is clear that the underlying economic issues will not disappear. Although this has not been a major priority for attorneys litigating on behalf of the mentally disabled, for legislators, for policy-makers, or for mental disability professionals, the issues are important and timeless ones. If the mega-issues of treatment and deinstitutionalization are to be effectively resolved, it is necessary that the meta-issue of economic rights be, once and for all, taken seriously.

${ }^{238}$ The use of the "pendulum" metaphor has grown exponentially in recent years. See, e.g., Durham \& LaFond, The Empirical Consequences and Policy Implications of Broadening the Statutory Criteria for Civil Commitment, 3 YALE L. \& POL. REV. 395, 398 (1985) ("the pendulum of public attitudes and state policy is swinging again"); Myers, Involumtary Civil Commitment of the Mentally Ill: A System in Need of Change, 29 VILL. L. REV. 367, 379 (1983-84) ("the pendulum may have swung too far"); Shuman, Innovative Statutory Approaches to Civil Commitment: An Overview and Critique," 13 L., MED, \& HEALTH CARE 284, 286 (1985) ("Now, it appears the swing toward dangerousness as an all exclusive criterion for commitment of the mentally ill has reached the height of its arc and has begun to reverse directions").

${ }^{239}$ See the Protection and Advocacy for Mentally Ill Individuals Act, 42 U.S.C. $\$ 10801$ et seq. (1986 Supp.) (Pamph. III).

240See generally "Last Frontier," supra note 4. See, e.g., Lelsz v. Kavanagh, 807 F. 2d 1243 (5 Cir. 1987), rev'g 629 F. Supp. 1487 (N.D. Tex. 1986) (vacating institutional rights consent decree under authority of Pennhurst, supra).

${ }^{24 !}$ The prototype recent case is Rivers $\%$ Katz, 67 N.1.' 2 d 485, 504 N.Y.S. 2d 74, 495 N.E. $2 d 337$ (Ct. App. 1986) (right to refuse treatment under state constitution), discussed extensively in "Last Frontier," supra note 4.

${ }^{242}$ See, e.g., Lehmann, Possidente \& Hawken, The Quality of Life of Chronic Patients in a State hospital and in Community Residences, 37 HOSP. \& COMMUN. PSYCH. 901 (1986).

${ }^{243}$ See, e.g., Kanter, Homeless Mentally III People: No Longer Out of Sight or Out of Mind, 3 N.Y.L.S. HUM. RTS, ANN. 331 (1986). 